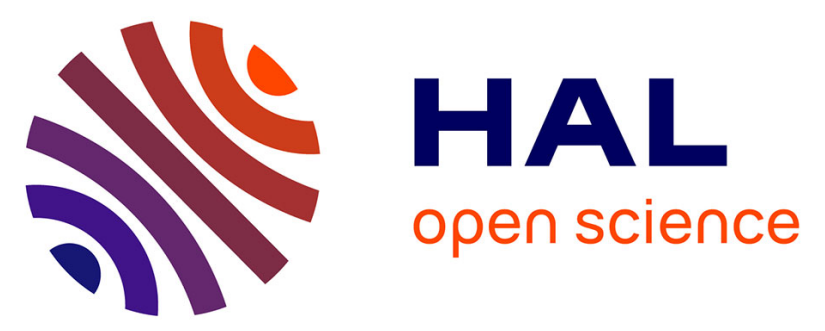

\title{
ERP Systems and BSC in the Operations Management: An Analysis of Results by Companies
}

Celso Affonso Couto, Oduvaldo Vendrametto, Pedro Neto, Marcos Morais, Antônio Sérgio Brejão

\section{- To cite this version:}

Celso Affonso Couto, Oduvaldo Vendrametto, Pedro Neto, Marcos Morais, Antônio Sérgio Brejão. ERP Systems and BSC in the Operations Management: An Analysis of Results by Companies. IFIP International Conference on Advances in Production Management Systems (APMS), Sep 2016, Iguassu Falls, Brazil. pp.478-484, 10.1007/978-3-319-51133-7_57 . hal-01615695

\section{HAL Id: hal-01615695 \\ https://hal.inria.fr/hal-01615695}

Submitted on 12 Oct 2017

HAL is a multi-disciplinary open access archive for the deposit and dissemination of scientific research documents, whether they are published or not. The documents may come from teaching and research institutions in France or abroad, or from public or private research centers.
L'archive ouverte pluridisciplinaire HAL, est destinée au dépôt et à la diffusion de documents scientifiques de niveau recherche, publiés ou non, émanant des établissements d'enseignement et de recherche français ou étrangers, des laboratoires publics ou privés. 


\title{
ERP Systems and BSC in the Operations Management: An Analysis of Results by Companies
}

\author{
Celso Affonso Couto, Oduvaldo Vedrametto, \\ Pedro Luiz Oliveira Costa Neto, Marcos de Oliveira Morais, and \\ Antonio Sérgio Brejão \\ Paulista University, São Paulo, Brazil \\ celsoacouto@hotmail.com
}

\begin{abstract}
This study objectives to verify, analyze and describe the difficulties and synergies between the strategic management methodology BSC (Balanced Scorecard) and integrated information system ERP (Enterprise Resource Planning) in the operations management. This is a multiple case study, which focuses on the relationship between these systems, contributing to a theoretical model that relates the characteristics of both management systems. Based on a broad theoretical framework that addresses several issues related to operations management, strategy, organizational system, ERP, performance indices and BSC, five companies were visited to questionnaires that enabled the identification of synergies, benefits, problems and difficulties between the BSC and ERP. In conclusion of this study, observations were made in relation to the BSC and ERP systems, especially regarding the difficulties identified and synergies between them in the operations management. Stood out in this work, the importance these two systems for planning, implementation and monitoring of strategy in organizations.
\end{abstract}

Keywords: Balanced Scorecard · Enterprise Resource Planning · Synergies and difficulties · Strategy.

\section{Introduction}

Maximsing productivity, profitability and competitiveness in today's business context is required in a globalized and competitive world stage, with rapid advances in production and information technology, and other transformations. Companies need to be prepared for the intensification of disputing for customers, using effective management technologies and appropriate to their needs [1].

The production puts the strategy into practice and management of information is one of the most important issues in planning and control of the production $[2]$.

One of the applications advancement of these technologies is the development of Integrated Management Systems, that it allows the information's integrated 
automation that results in transactions made through the various processes of management and operation carried out within the company.

The German company called SAP (Systeme, Anwendungen, Produkt) with its software that enables the full connection between all functional areas of a company, as well as many industrial functions of the planning and production control [3].

Kaplan and Norton [4] developed the concept of the BSC, strategic management system initially used as monitoring tool performance and strategy control; it evolved into its potential, going to be treated as an important strategic management system in organizations.

To the BSC methodology dealing with excellence and effectiveness to the company's strategy, it must have the support of an "Integrated Management System" - ERP [5].

\section{Formulation of the Problem/Main Issue Search}

This study aimed to examine whether the ERP meets the BSC strategic management system requirements in accordance with the following specific objectives:

- Identify if there is integration between ERP and BSC in the operations;

- Identify benefits that ERP provides the BSC in the operations;

- Identify problems and difficulties of the ERP to meet the BSC; and

- Identify the consequences for the organization of the problems and difficulties generated by ERP to meet the BSC in the operations.

\section{Literature Review}

It presents a solid theory necessary to support the study of operations management, strategy, organizational systems, ERP systems, performance indicators and BSC strategic management system.

The topics were discussed as a theoretical basis for individual understanding of each theory, the relationship between themselves and the research objective, which is check the alignment (synergies / difficulties) between BSC and ERP in the operations management in implementing the strategy in organizations.

\subsection{Operations Management}

The operations management area develops planning, coordination and execution of all activities that create goods and provide services. Issues important as productivity, competitiveness and strategy relate to that area [1].

Information systems like MRP (Materials Requirements Planning ), MRP II (Resources Planning ), ERP (Enterprise Resource Planning) are tools that contribute directly to implementation of the strategy in the operations [6]. 


\section{$3.2 \quad$ Strategy}

The competition in several business segments, is very fierce, so that management systems as integrated BSC and ERP would create a competitive advantage, emerging unique opportunities, offering benefits to be realized by customers, expanding into new products and services.

It is seen as a corporate resource that supports strategies at the operational level, as the case of BSC methodology, or direct the strategies at a higher level, supporting the business in achieving competitive advantage [7].

\subsection{Organizational System}

The life cycle of an ERP-System extended phases of systems life cycle, as treated by Systems Theory.

The decision to adopt or not a technological trend would be outside the company's control when certain technology becomes a widespread use. Thus, companies have no alternative to adopt them or not, and are taken by majority decision, because if not come to adopt the new trend, compromise their competitiveness [8].

\subsection{Systems ERP (Enterprise Resource Planning)}

It sets up define an ERP system as a software package computes applications that support most business processes and information needs of an organization, such as production, supply chain, human resources, accounting, administration, sales, etc. The purpose of ERP is to integrate all areas and functions of the organization into a unified system for obtaining information in an efficient and timely manner [9].

\subsection{Performance Indicators}

Because the BSC use of performance indicators for analyzing the results in organizations, it is important to address some concepts of these indicators.

Indicators are quantifiable forms of representations of the characteristics of products and processes. They are used by the organization to control and improve the quality and performance of its products and processes over time [10].

Indicators help the organization to concentrate their efforts towards strategy and test the progress of the organization.

\subsection{Balanced Scorecard - BSC}

The term Balanced Scorecard was coined by Robert Kaplan and David Norton in a joint article in the Harvard Business Review in 1992 (HBR on Measuring Bodyrate performance: Measuring performance in the Organization of the future) [4].

The BSC is a method of business management in which strategic objectives are established and monitored by defining performance indicators [11].

The BSC methodology is based on four perspectives around the mission, vision and strategy of the organization [12]. 
The Strengths of BSC. Outcome indicators of alignment with trend indicators; The BSC considers different interest groups in the analysis and implementation of strategy; Communication strategy; Promotes organizational synergy; The BSC is directed and focused on actions; translates the strategy into objectives and measures; Organization's alignment with the strategy; Constructs a strategic management system and links the strategy with planning and budget; Facilitates communication of strategic objectives, focusing on the employees in their implementation; The BSC helps reduce the amount of information used to set a minimum critical and vital indicates pain.

The Weaknesses of BSC. Does not separate cause and effect in time; Lack of mechanisms for validation; Link between strategy and operation is insufficient; Very internally focused.

\section{Methodology}

The method study of multiple cases is appropriate in this work because, in his empirical research, we sought to describe and analyze the integration and synergy between the BSC and ERP, taking into account the business environment in which they occur. Are part of that context the reasons for the need for integration between the BSC and ERP associated with implementing the company's strategy at all hierarchical levels. This is a descriptive and explanatory research.

It is reported that "the use of study cases specifically to the area of information systems is adequate for capturing the knowledge of professionals and build theories from this ". Both in the case of the ERP system and in the BSC, it is interesting the experience obtained in practice by the professionals involved in the implementation and utilization of these management systems [13].

They were used in this study unstructured interviews made with the main participants of the implementation of processes and use of ERP systems and BSC, analysis of documents and records and direct observation.

Script's questions were based on the following issues:

- Why the surveyed companies have decided to use the ERP and BSC systems?

- How occurred the supplier selection processes in the sourced companies?

- As implementation processes occurred in the surveyed companies? What problems occurred during the implementation?

- What benefits have been or are being obtained with the use of ERP and BSC systems? How and why were obtained?

- What difficulties occurred or are occurring on the use of ERP systems and BSC in the surveyed companies? How and why that happened?

- What changes the ERP and the BSC system brought to the respondent department? And for the company?

- Is there synergy / integration between ERP and BSC system? Because yes? Why not? 
- What are the improvements to meet synergy / integration between ERP systems and BSC?

- Can you list the ERP system and BSC system competitiveness gains in business?

- What are the next steps of the company in relation to information technology and business management methodology?

It was used in this work, for the presentation of cases, the analytical-linear model described by Yin [14].

Case reports were from the following points:

- If the context (type of business, size, description of the decision-making and choice of ERP, BSC, which used package and other factors considered relevant);

- Description of the implementation process of ERP and the BSC and its main problems;

- Benefits and problems encountered in the case.

The analysis of the cases was made considering the following points:

- Differences between the contexts of different companies;

- Similarities and differences between the results obtained in different companies;

- New ideas generated from the comparison of the cases;

- Analysis of the results against the initial proposals and the theoretical framework developed in the literature.

Some precautions to interpretation of the data were taken, some of them such as:

- Questionnaire used to guide the interviews;

- The researcher himself did the interviews, transcripts and writing cases;

- The use of multiple sources of evidence (triangulation) to confirm or supplement the information obtained in the interviews;

- Confirmation of case descriptions by the respondents.

\section{Discussion of the Case Study Results}

This multiple case study was conducted in five companies: power company, beverage company, steel industry, hospital and pharmaceutical industry. They all operate with ERP and BSC.

The research objectives were to identify whether there is integration between ERP and BSC in the operations, identify the benefits that ERP can offer the BSC in the operations, identify the problems and difficulties of the ERP to meet the BSC and identify the consequences for the operations problems and difficulties generated by ERP to meet the BSC.

The main considerations are presented, according to understanding of the comparative analysis between the companies surveyed. They are: 
- In all businesses was implemented and first deployed ERP, for over ten years; and when it occurred, it was not thought to implementing the BSC;

- In all companies, the implementation of ERP occurred because the existing systems did not meet the needs of businesses;

- In all businesses and in all ERP modules were necessary customizations and improvements to meet the operations and business enterprises;

- In all companies, the planned cost for ERP implementation was not enough;

- In all companies, training for key users of ERP and more users was not enough;

- Despite all the difficulties and high costs in implementation and even in the initial phase of ERP implementation, all companies recognize the importance of ERP;

- In all companies implemented the BSC for more than seven years;

- The company decided to implement the BSC to improve the strategy, taking the strategy paper and turning it into actions in all areas;

- Companies expected the BSC communication strategy, synergies between the areas of strategy and translation into objectives and concrete actions;

- Companies have focused on four perspectives addressed by the BSC, namely: financial perspective, customer, internal processes and learning and growth;

- All companies reported that the BSC has improved the understanding of the strategy of the company, also improving its competitive edge, market share and especially its profitability and relationships with stakeholders;

- In all companies it was essential to have customizations and improvements in the ERP to attend the BSC;

- The main synergies between the BSC and ERP are planning, estimating, monitoring and reporting of performance indicators, speed, quality and confiability of information;

- Some benefits generated by the integration and synergy between the BSC and ERP: monitoring of the objectives and goals of the company; correction in a timely manner in decisionmaking, management reports available anytime and improvements in processes and cost rationalization;

- In every business synergy and integration of ERP and BSC brought productivity gains, increasing market participation, transparency and quality of information provided to stakeholders, competitive advantages and increased of profitability.

\section{Considerations and Recommendations}

In summary, for managers of enterprises, ERP information is generated in real time, systematized with clarity and transparency, in short summary, sequential and projected, numerical, narrative or graphic, easy understanding, and that support the needs of each area, and provide financial and management reports that attend the BSC and decision-making, through the planning, implementation and monitoring of the company's strategy. 
In the surveyed companies show that the ERP brings the possibility of real gains in business efficiency, control and which provides synchronization of activities that require your best planning. Its integration with the BSC provides efficiency gains for the company. The answers of respondents indicated efficiency improvements and gains in competitiveness, through the integration between the ERP and the BSC or extension of its functionality.

However, in addition to the BSC, there are other systems and strategic management tools that could be studied with the use of ERP and enterprise management system that supports the management of information aimed at processing efficiently, transparent, principled and reliable to describe, implement and manage the strategy at all levels of the company, linking objectives, initiatives and measures with the overall strategy of the company.

\section{References}

1. Neumann, C.: Gestão de Sistemas de Produção e Operações. Rio de Janeiro (2013)

2. Slack, N., Chambers, S., Johnston, R.: Administração da Produção. Atlas (2009)

3. Stevenson, W.J.: Administration of Production Operations. LTC, Rio de Janeiro (2001)

4. Kaplan, R.S., Norton, D.P.: Having Trouble with Your Strategy? Then Map it. Focusing Your Organization on Strategy — with the Balanced Scorecard p. 49 (2000)

5. Emílio Filho, H.: Balanced Scorecard e a Gestão Estratégica: Uma Abordagem Prática. Editora Campus (2005)

6. Laugeni, F.P., Martins, P.G.: Administração da Produção. São Paulo: Saraiva (2006)

7. Canépa, P.C.V., Rigoni, E.H., Brodbeck, n.F.: Práticas de Alinhamento Estratégico: Um Estudo Exploratório em Organizações Industriais e de Serviços. Revista de Administração Mackenzie 9(1) (2008)

8. Brodbeck, A.F., Henrique Rigoni, E., Hoppen, N.: Strategic alignment maturity between business and information technology in southern brazil. Journal of Global Information Technology Management 12(2), 5-32 (2009)

9. Souza, C., Zwicker, R.: Sistemas ERP: Estudo de Múltiplos Casos em Empresas Brasileiras. SOUZA, C.; SACCOL, A. Sistemas ERP no Brasil: teoria e casos. São Paulo: Atlas (2003)

10. Takashina, N.T.F., X., M.C.: Indicators of Quality and Performance. Rio de Janeiro: Qualitymark (1997)

11. Cesar, R.: http://computerworld.com.br/tecnologia/2003/03/28/idgnoticia. 2006-05-15.5335549649

12. Kaplan, R.S., Norton, D.P.: The Balanced Scorecard: Translating by Luiz Euclydes T. F. Filho. Elsevier, Rio de Janeiro (1997)

13. Souza, C.A.d., Zwicker, R.: Sistemas Integrados de Gestão Empresarial: Estudos de Casos de Implementação de Sistemas ERP. Faculdade de Economia, Administração e Contabilidade (2000)

14. Yin, R.K.: Case Study Research: Design and Methods. Bookman (2010) 